American Research Journal of Agriculture

ISSN (Online) : 2378-9018

Volume 5, Issue 1, 1- 8 Pages

DOI: 10.21694/2378-9018.19002

Research Article

Open Access

\title{
Effects of 4BAC-Extra Probiotic Supplementation Levels on Nutrient Digestibility and Blood Parameters of Sasso Laying Hens
}

\author{
HARUNA, H. S. ${ }^{1,2}$, ARI, M.M.*2, ADUA, M.M. ${ }^{2}$, YAKUBU, ${ }^{2}$ \\ ${ }^{1}$ Department of Animal Production Technology, Nasarawa State College of Agriculture Pmb 33, Lafia. \\ ${ }^{2}$ Department of Animal Science, Faculty of Agriculture, Nasarawa State University Keffi, Shabu-Lafiacampus. \\ harunahadizasalihu@gmail.com; arimaikano@yahoo.com
}

\begin{abstract}
This study was conducted to evaluate the effects of 4Bac-Extra Probiotic supplementation levels on nutrient digestibility and blood parameters of sasso laying hens using One Hundred and Sixty (160) Sasso layers that were randomly assigned into four treatments with four replicates each representing T1- 0, T2- 5, T310 and T4- 15\% supplementation of basal feed with 4Bac-Extra probiotics. During the sixty two days (62 d) experimental period, the birds were managed on deep litter and provided with the experimental feeds and water ad libitum. The parameters measured were nutrient digestibility, biochemical and hematological indices. Nutrient digestibility indicates a significant $(\mathrm{P}<0.05)$ difference between treatments with better and higher values in diet $\mathrm{T}_{4}$ for most nutrients measured while Hematological and serum biochemical showed no significant $(\mathrm{P}>0.05)$ difference between treatments. The results obtained from this experiment indicate that the effects of 4-Bac Extra probiotics were only slight. However, inclusion of $5-10 \%$ was found to have satisfactory effects on birds.
\end{abstract}

\section{INTRODUCTION}

The use of In-feed antibiotic supplements to achieve a balance between birds' productive performance and health improvement is gradually in the decline in most countries of the world due to its effects on the animal and humans who are the consumers of animal products. Therefore, researchers are looking in the direction of natural means of replacing the use of in- feed antibiotics in poultry nutrition (Genedy Salwa and Zeweil, 2003; Ibrahim et al., 2005). Thus, the use of exogenous probiotics in poultry feeds to improve bird performance is fast gaining acceptability as a good replacement (Ari et al., 2016).

The utilization of feeds and additives are measured by their conversion into useful nutrients readily available for uptake and conversion for maintenance and production needs of the animals. Nutrient digestion and serum assay provides biological platforms for assessment. Dierick (1989) reported that probiotics increase activity of intestinal enzymes and digestibility of nutrients. Similarly O'Sullivan et al. (1992) reported that probiotics change complex foods into simpler forms in body and they are able to complement many deficiencies in our digestive system such as production of vitamin $\mathrm{K}$ and absorption of certain ions. It is important to note that probiotics maintain normal intestinal microbiota by competitive exclusion and antagonism against disease causing microbes, and therefore this role is exploited in maintaining health of man and animals or birds. Studies have shown that probiotics influences serum profile and composition of haematological parameters (Corcoran et al., 2005; Jain, 2010; Aro and Akinmoegun, 2012). This study was aimed at evaluating the effects of 4bacextra probiotic supplementation levels on the nutrient digestibility and serum profile of sasso laying hens.

www.arjonline.org

Page 1 
Effects of 4BAC-Extra Probiotic Supplementation Levels on Nutrient Digestibility and Blood Parameters of Sasso Laying Hens

\section{Materials AND Methods}

\section{Experimental Site}

The study was conducted at the Livestock Teaching and Research Farm of Faculty of Agriculture, Shabu-Lafia Campus, Nasarawa State University, Keffi. It is located on latitude $08.35^{\circ} \mathrm{N}$ and longitude $08.33^{\circ} \mathrm{E}$ in the Guinea Savannah Zone of North Central Nigeria.

\section{Source of Feed Ingredients}

Maize grain was purchased from Doma market, groundnut cake, premix, methionine, lysine, limestone and bone meal were purchased in Jos Plateau State while 4-Bac Extra (probiotics) was bought from Mid-Century Agro-Allied Venture Limited Lagos, Lagos State.

\section{Experimental Diets and Feed Preparation}

The experimental diets were formulated using Feed win Software to provide 2735kcal of metabolizable energy and $16.25 \%$ of crude protein as basal diets. The experimental treatment diets were divided into four treatment groups representing $0.00,0.125,0.250$, and $0.357 \mathrm{mg} / 100 \mathrm{~g}$ supplementation of diet with 4Bac-Extra probiotic through addition to basal diet; this represents experimental treatments $\mathrm{T}_{1}, \mathrm{~T}_{2}, \mathrm{~T}_{3}$ and $\mathrm{T}_{4}$. The formulated diets were prepared using hammer mill to grind, the probiotic was add accordingly prior to mixing and pelleting. The feeds were pelleted using a $2 \mathrm{~mm}$ single screw extruder.

\section{Experimental Treatment and Data Collection}

One hundred and sixty (160) pre-peak sasso laying birds were randomly allocated to four treatment groups of Four (4) replicate, each treatment group was fed adlibitum treatments diets $\mathrm{T}_{1}, \mathrm{~T}_{2}, \mathrm{~T}_{3}$ and $\mathrm{T}_{4}$ respectivelyduring experimental period. The birds were raised under the deep litter while routine management practices and water was provided throughout. The following data were taken:

\section{Nutrient Digestibility}

The nutrient utilization of diets containing different levels of probiotic evaluation was conducted using sixteen (16) birds from each treatment and four (4) per replicates birds that were transferred to the metabolic cages. A 24 hr adjustment period in cages was allowed, dried sacks were spread below the cages to collect faecal droppings daily for seven (7) days. Feacal collections were dried and weighed after which it was put in dessicator. All the samples were bulked by replicates weight and thoroughly mixed and sub samples were taken for analysis of their proximate constituents. Apparent nutrient digestibility was calculated using the formula:

Apparent Nutrient Digestibility $=\frac{\text { Nutrient Consumed }- \text { Nutrient Voided }}{\text { Nutrient Consumed } 1} \times 100$

\section{Haematological and Serum Biochemistry Parameters}

Blood samples were collected from the wing vein using $2 \mathrm{ml}$ syringe and needle at the end of the experiment from each replication of the treatment and stored in plastic sample bottles containing EDTA (ethylene diamine tetraacetic acid) for haematological studies. While another $3 \mathrm{ml}$ each was deposited into anticoagulant free plastic tubes and allowed to clot at room temperature, within 3 hours of collection. The serum samples were stored at a temperature of $-20^{\circ} \mathrm{C}$ prior to biochemical analysis. The haematological analysis was carried out according to the procedure by Jain (1986) to determine: packed cell volume (PVC), Haemoglobin concentration (HC), Erythrocytes (RBC), Leucocytes Count (WBC). The biochemical parameters were analyzed according to 
Effects of 4BAC-Extra Probiotic Supplementation Levels on Nutrient Digestibility and Blood Parameters of Sasso Laying Hens

the method of Ajagbonna et al. (1999), Uko et al. (2000) and Ahamefule et al. (2008) to determine: total protein, albumen, globulin, urea, creatinine, Alanin Amino Transferase (ALT), Aspartate Amino Transferase (AST) and total cholesterol.

\section{Chemical Analysis}

The proximate composition for each of the experimental treatment diets were determined according to Association of Official Analytical Chemists (AOAC) (2006) methods, while Metabolizabe Energy of the experimental diets was calculated using Pauzenga (1985) equation.

\section{Statistical Analysis}

Results obtained from the study were subjected to Analysis of Variance (ANOVA) using SPSS 20 while Duncan's multiple range test (DMRT) was applied to separate the means were applicable (Duncan,1955).

\section{RESULTS AND Discussion}

The result obtained indicate significant $(\mathrm{P}<0.05)$ differences in the mean digestibility values ofcrude protein in $\operatorname{diet} \mathrm{T}_{1}$ (control, 90.35), and the highest value, followed by $\operatorname{diet} \mathrm{T}_{4}\left(15 \%, 85.84\right.$ probiotics, $\operatorname{diet} \mathrm{T}_{2}(5 \%$ probiotics, 82.89), Diet $\mathrm{T}_{3}(10 \%$ probiotics, 81.98$)$ are similar. Ether extract in $\operatorname{diet}\left(\mathrm{T}_{4}\right)$ with $15 \%$ probiotics 90.36 , diet $\left(\mathrm{T}_{2}\right)$ with $5 \%$ probiotic has 87.29 and to diet $\mathrm{T}_{1}$ (control with 88.02) are similar and higher compared todiet $\mathrm{T}_{3}$ with $10 \%$ probiotics and 80.66 .

Dry matter digestibility in diet $\mathrm{T}_{4}$ with $15 \%$ probiotic has the highest value of $(80.44)$ while diet $\mathrm{T}_{3}(10 \%)$ with 70.92 value, diet $\mathrm{T}_{2}$ (72.37) with (5\%) probiotics and diet $\mathrm{T}_{1}(0 \%)$ which is the control with 72.25 are similar. Crude fibre in diet $\left(\mathrm{T}_{1}\right)$ is similar to $\mathrm{T}_{4}(15 \%$ probiotics $)$ with 91.05 but higher compared to diet $\mathrm{T}_{3}(10 \%$ probiotic) 88.52 and diet $\mathrm{T}_{2}(5 \%$ probiotics $)$ which are similar. Nitrogen free extract in diet $\mathrm{T}_{4}(15 \%$ probiotics, 97.72) has the highest value. Diet $\mathrm{T}_{1}$ (control) with 91.02 has the lowest value, while $\operatorname{diet} \mathrm{T}_{3}(10 \%$ probiotic, $94.00)$ and diet $\mathrm{T}_{2}(5 \%$ probiotics 93.20$)$ have similar value.

Calcium in diet $\mathrm{T}_{2}(5 \%$ probiotics 94.46$)$, diet $\mathrm{T}_{1}$ (control, 93.44 ) and diet $\mathrm{T}_{4}(15 \%$ probiotic) 94.29 are similar while $\mathrm{T}_{3}$ has the lowest value. Diet $\mathrm{T}_{3}\left(10 \%, 92.18^{\mathrm{b}}\right)$ has the lowest value.

Phosphorus in diet $\mathrm{T}_{4}(15 \%$ probiotics $)$ is higher compared to $\mathrm{T}_{3} . \mathrm{T}_{1}, \mathrm{~T}_{2}$, and $\mathrm{T}_{3}$ are similar diet $\mathrm{T}_{2}(5 \%, 93.94)$.

The total protein in the blood showed no significant $(\mathrm{P}>0.05)$ diet $\mathrm{T}_{1}$ which is the control shown the highest value 56.75. Diet $\mathrm{T}_{2}\left(5 \%\right.$ probiotic 51.25 and diet $\mathrm{T}_{3}(10 \%$ probiotics) with 51.60 are similar, with diet having higher value. Diet $\mathrm{T}_{4}(15 \%$ probiotics $)$ have the lowest value of 48.50 when compared to other treatments. The mean of Albumin $(\mathrm{g} / \mathrm{l})$ shows no significant $(\mathrm{P}<0.05)$ diet $\mathrm{T}_{3}(10 \%$ probiotics $)$ shows the highest value of Albumin (g/l). Diet $\mathrm{T}_{2}\left(5 \%\right.$ probiotic) have 20.85 while diet $\mathrm{T}_{1}(0 \%$ control $) 20.08$ and $\operatorname{diet} \mathrm{T}_{4}(5 \%$ probiotic) 20.03 are similar with diet $\mathrm{T}_{4}$ with the lowest value. The mean of Globulin (g/l) shows no significant diet $\mathrm{T}_{4}$ (15\%) 20.03 have the lowest value, followed by diet $\mathrm{T}_{3}$ (10\% probiotic), $30.15 \operatorname{diet} \mathrm{T}_{2}$ (5\% probiotic) 30.63 and diet $\mathrm{T}_{1}$ (control $0 \%$ probiotic) 36.68 with highest value respectively. The mean values obtained for urea (Mmol/L shows no significance). The diet $\mathrm{T}_{1}$ (control 0\% probiotics 2.80 have the highest value. Diet $\mathrm{T}_{4}(15 \%$ probiotics 2.63 , diet $\mathrm{T}_{2} 5 \%$ probiotics 2.60 , diet $\mathrm{T}_{3} 10 \%$ probiotic 1.78 have lower value with diet $\mathrm{T}_{3}$ with lowest respectively.

The mean of creatinine (Mmol/L) shows no significant treatment $\mathrm{T}_{2}(5 \%$ probiotic 60.25$)$ have the highest value. Diet $\mathrm{T}_{1}$ (control 54.50), $\mathrm{T}_{4}(15 \%)$ diet $10 \%$ probiotic 53.50 with the lowest valve.

The mean of ALT (g/l) value in diet $\mathrm{T}_{4}\left(15 \%\right.$ probiotics, 37.75\%) have the highest value. Diet $\mathrm{T}_{1}$ (control 25.75 
Effects of 4BAC-Extra Probiotic Supplementation Levels on Nutrient Digestibility and Blood Parameters of Sasso Laying Hens

and diet $\mathrm{T}_{2}$ (5\% probiotics, 25.60) are similar with slight increase in diet $\mathrm{T}_{1} 25.75$ which is the control while $\operatorname{diet} \mathrm{T}_{3}(10 \%$ probiotic 13.00$)$ with lowest value respectively. The mean of AST (g/l) value shows no significant diet $\mathrm{T}_{2}\left(5 \%\right.$ probiotic 32.50 and diet $\mathrm{T}_{4}\left(10 \%\right.$ probiotic) have same value. Diet $\mathrm{T}_{4}(15 \%$ probiotic 46.13$)$ have increase in the volume of the AST (g/l) while their decrease in diet $\mathrm{T}_{1}(0 \%, 25.75)$. The mean total cholesterol (Mmol/L) shows no significant diet $\mathrm{T}_{2}(5 \%$ probiotic 3.20) have the highest total cholesterol (Mmol/L) Diet $\mathrm{T}_{1}$ (control, 2.85 and diet 10\% probiotic 2.63 increase. Diet $\mathrm{T}_{4}(15 \%$ probiotic 2.00 ) show decrease in Total cholesterol level.

Table1. Experimental diets for layer birds

\begin{tabular}{|c|c|c|c|c|}
\hline Ingredient & T1 & T2 & T3 & T4 \\
\hline Based diet & \multicolumn{4}{|c|}{$\mathrm{Kg} / 100 \mathrm{Kg}$} \\
\hline Maize & 55.52 & 55.52 & 55.52 & 55.52 \\
\hline Groundnut cake & 19.8 & 19.8 & 19.8 & 19.8 \\
\hline Maize bran & 8.00 & 8.00 & 8.00 & 8.00 \\
\hline Rice bran & 4.00 & 4.00 & 4.00 & 4.00 \\
\hline Limestone & 7.00 & 7.00 & 7.00 & 7.00 \\
\hline Bone meal & 5.00 & 5.00 & 5.00 & 5.00 \\
\hline L-lysine & 0.10 & 0.10 & 0.10 & 0.10 \\
\hline DL-methionine & 0.08 & 0.08 & 0.08 & 0.08 \\
\hline Salt & 0.25 & 0.25 & 0.25 & 0.25 \\
\hline *Premix & 0.25 & 0.25 & 0.25 & 0.25 \\
\hline Total & 100 & 100 & 100 & 100 \\
\hline \multicolumn{5}{|l|}{ Probiotic supplements } \\
\hline$* * 4 B a c-E x t r a$ & 0.00 & 0.125 & 0.250 & 0.357 \\
\hline \multicolumn{5}{|c|}{ Calculated nutrient and energy composition } \\
\hline Energy (kcal/kg, ME) & 2735.43 & 2735.43 & 2735.43 & 2735.43 \\
\hline Crude protein $(\%)$ & 16.24 & 16.24 & 16.24 & 16.24 \\
\hline Crude fibre (\%) & 4.10 & 4.10 & 4.10 & 4.10 \\
\hline Crude fat $(\%)$ & 4.63 & 4.63 & 4.63 & 4.63 \\
\hline Methionine (\%) & 0.33 & 0.33 & 0.33 & 0.33 \\
\hline Lysine (\%) & 0.61 & 0.61 & 0.61 & 0.61 \\
\hline Ca $(\%)$ & 3.63 & 3.63 & 3.63 & 3.63 \\
\hline$(\mathrm{P})(\%)$ & 0.75 & 0.75 & 0.75 & 0.75 \\
\hline
\end{tabular}

*Premix to provide the following per Kg of diet Calcium $27.3 \%$, Crude fibre $0.02 \%$,Vitamin A (E672) 4000000 IU, Vitamin D3 (E671) 1000000 IU. Vitamin E (all-rac- $\alpha$-tocopheryl acetate) (3a700) 6000 IU. Vitamin B1 (thiamine mononitrate) $600 \mathrm{mg}$. Vitamin B2 (riboflavin) $1600 \mathrm{mg}$. Vitamin B6 (pyridoxine hydrochloride) (3a831) 1200 mg. Vitamin B12 (cyanocobalamin) $6000 \mu \mathrm{g}$. Vitamin K3 (menadione nicotinamide bisulfite) $800 \mathrm{mg}$. Pantothenic acid (calcium-D-pantothenate) (3a841) $3200 \mathrm{mg}$. Niacinamide (3a314) $8000 \mathrm{mg}$. Biotin (3a316) $40000 \mathrm{mg}$. Folic acid (3a316) $200 \mu \mathrm{g}$. Choline chloride (3a890) $80000 \mathrm{mg}$. Iron (E1; as ferrous carbonate) $16000 \mathrm{mg}$. Iodine (E2; as calcium iodate anhydrous) $600 \mathrm{mg}$. Copper (E4; as cupric sulphate pentahydrate) $4000 \mathrm{mg}$. Manganese (E5; as manganous oxide) $32000 \mathrm{mg}$. Zinc (E6; as zinc oxide) $20000 \mathrm{mg}$. Selenium (E8; as sodium selenite) $60 \mathrm{mg}$.

* Composition of Probiotic 4Bac-Extra 
Effects of 4BAC-Extra Probiotic Supplementation Levels on Nutrient Digestibility and Blood Parameters of Sasso Laying Hens

Vitamin $\alpha$ tocopherol $700100 \mathrm{mg}$, lactobacillus acidophilus 45,000 Million, live yeast cultures of Saccharomyces cerevisiae sc 47,125 million c.f.u, protein $11.6 \%$, crude fibre $1.3 \%$, moisture $10.9 \%$, crude ash $14.0 \%$, crude oil and fat $2.6 \%$, sodium $0 \%$, Lysine $0 \%$, Methionine $0 \%$ total sugar $70 \%$.

Table2. Chemical composition of experimental diets

\begin{tabular}{|l|l|l|l|l|l|l|l|l|}
\hline Treatment & DM & NFE & CP & EE & CF & Ash & Ca & P \\
\hline T1 & 95.52 & 62.85 & 16.52 & 1.80 & 9.4 & 4.95 & 3.55 & 2.11 \\
\hline T2 & 95.00 & 60.35 & 16.49 & 2.46 & 11.1 & 4.6 & 2.95 & 2.00 \\
\hline T3 & 95.20 & 59.98 & 16.49 & 3.00 & 10.7 & 5.03 & 3.75 & 2.06 \\
\hline T4 & 71.20 & 54.96 & 16.69 & 2.80 & 11.7 & 5.05 & 3.7 & 2.156 \\
\hline
\end{tabular}

DM- Dry Matter; CP - Crude Protein; EE - Ether Extract; CF - Crude Fibre; NFE - Nitrogen Free Extract; Ca Calcium; P - Phosphorous.

Table3. Nutrients digestibility by Sasso hens fed diets containing different levels of probiotics

\begin{tabular}{|l|l|l|l|l|l|}
\hline Digestibility & $\mathbf{T}_{\mathbf{1}} \mathbf{( 0 \% )}$ & $\mathbf{T 2} \mathbf{( 5 \% )}$ & $\mathbf{T}_{\mathbf{3}} \mathbf{( 1 0 \% )}$ & $\mathbf{T}_{\mathbf{4}} \mathbf{( 1 5 \% )}$ & SEM \\
\hline Crude protein (\%) & $90.35^{\mathrm{a}}$ & $82.89^{\mathrm{c}}$ & $81.98^{\mathrm{c}}$ & $85.84^{\mathrm{b}}$ & $0.89^{*}$ \\
\hline Ether extract (\%) & $88.02^{\mathrm{a}}$ & $87.29^{\mathrm{a}}$ & $80.66^{\mathrm{b}}$ & $90.36^{\mathrm{a}}$ & $1.14^{*}$ \\
\hline Dry matter (\%) & $72.25^{\mathrm{b}}$ & $72.37^{\mathrm{b}}$ & $70.92^{\mathrm{b}}$ & $80.44^{\mathrm{a}}$ & $1.11^{*}$ \\
\hline Crude fibre (\%) & $94.00^{\mathrm{a}}$ & $87.37^{\mathrm{c}}$ & $88.52^{\mathrm{bc}}$ & $91.05^{\mathrm{ab}}$ & $0.79^{*}$ \\
\hline Nitrogen-free extract (\%) & $91.02^{\mathrm{c}}$ & $93.20^{\mathrm{b}}$ & $94.00^{\mathrm{b}}$ & $97.72^{\mathrm{a}}$ & $0.64^{*}$ \\
\hline Absorption & & & & & \\
\hline Calcium (\%) & $93.44^{\mathrm{a}}$ & $94.46^{\mathrm{a}}$ & $92.18^{\mathrm{b}}$ & $94.29^{\mathrm{a}}$ & $0.29^{*}$ \\
\hline Phosphorus (\%) & $93.70^{\mathrm{ab}}$ & $93.94^{\mathrm{ab}}$ & $93.17^{\mathrm{b}}$ & $94.92^{\mathrm{a}}$ & $0.26^{*}$ \\
\hline
\end{tabular}

NS- Not Significant $(\mathrm{P}>0.05)$,

*- Significant Difference $(\mathrm{P}<0.05)$,

**- Highly Significant $(\mathrm{P}<0.01)$, SEM- Standard Error of Means,

abcd- Means denoted by Different alphabets in the same row are significant.

Table4. Effect of 4Bac-extra probiotic on serum biochemical parameters of Sasso hen fed different levels

\begin{tabular}{|l|l|l|l|l|l|}
\hline & $\mathbf{T}_{\mathbf{1}}(\mathbf{0} \%)$ & $\mathbf{T}_{\mathbf{2}} \mathbf{( 5 \% )}$ & $\mathbf{T}_{\mathbf{3}} \mathbf{( 1 0 \% )}$ & $\mathbf{T}_{\mathbf{4}} \mathbf{( 1 5 \% )}$ & $\mathbf{S E M}$ \\
\hline Total Protein (g/l) & 56.75 & 51.25 & 51.00 & 48.50 & $2.24^{\mathrm{NS}}$ \\
\hline Albumin (g/l) & 20.08 & 20.63 & 20.85 & 20.03 & $0.37^{\mathrm{NS}}$ \\
\hline Globulin (g/l) & 36.68 & 30.63 & 30.15 & 28.48 & $2.20^{\mathrm{NS}}$ \\
\hline Urea (Mmol/L) & 2.80 & 2.60 & 1.78 & 2.63 & $0.18^{\mathrm{NS}}$ \\
\hline Creatinine (Mmol/L) & 54.50 & 60.25 & 53.50 & 54.50 & $2.68^{\mathrm{NS}}$ \\
\hline Alanine Aminotransferase ALT (U/L) & 25.75 & 25.00 & 13.00 & 37.75 & $4.81^{\text {Ns }}$ \\
\hline Aspartate Aminotransferase AST (U/L) & 25.75 & 32.50 & 32.50 & 46.13 & $4.48^{\text {NS }}$ \\
\hline Total Cholesterol (Mmol/L) & 2.85 & 3.20 & 2.63 & 2.00 & $0.19^{\mathrm{NS}}$ \\
\hline
\end{tabular}

NS- Not Significant ( $\mathrm{P}>0.05)$; SEM- Standard error of means. 
Effects of 4BAC-Extra Probiotic Supplementation Levels on Nutrient Digestibility and Blood Parameters of Sasso Laying Hens

Table5. Haematological characteristics of Sasso hens fed diets containing different levels 4Bac-Extra of probiotics

\begin{tabular}{|l|l|l|l|l|l|}
\hline & $\mathbf{T}_{\mathbf{1}}(\mathbf{0} \%)$ & $\mathbf{T}_{\mathbf{2}} \mathbf{( 5 \% )}$ & $\mathbf{T}_{\mathbf{3}} \mathbf{( 1 0 \% )}$ & $\mathbf{T}_{\mathbf{4}} \mathbf{( 1 5 \% )}$ & $\mathbf{S E M}$ \\
\hline Packed Cell Volume (\%) & 26.50 & 32.00 & 28.50 & 24.50 & $3.02^{\text {NS }}$ \\
\hline Haemoglobin (g/dL) & 8.45 & 7.60 & 6.83 & 8.03 & $1.18^{\text {NS }}$ \\
\hline Red Blood Cells (x10 $12 / \mathrm{L})$ & 2.47 & 2.81 & 1.92 & 2.34 & $0.33^{\text {NS }}$ \\
\hline White Blood Cells (x 10 $/ \mathrm{L})$ & 94.25 & 97.50 & 104.50 & 72.00 & $11.68^{\text {NS }}$ \\
\hline
\end{tabular}

SEM- Standard Error of Means, NS- Not Significant $(\mathrm{P}>0.05)$

\section{Discussion}

The result obtained indicate significant $(\mathrm{P}>0.05)$ differences with inclusion of probiotic in the experimental diet at the rate ranging from $0 \%$ to $15 \%$. This result agreed with the study reported by Nawaz et al. (2016) that observed significant $(\mathrm{P}>0.05)$ effect on overall performance and nutrient digestibility in birds fed diet containing probiotic. It also agreed with observation made by Zhang et al. (2015) that an increased in apparent digestibility of crude protein and total phosphorus was reported following probiotic administration.

The observation made in this study are in line with the reports of Mountzouris et al. (2010) who reported that probiotic inclusion level had a significant effect on broilers growth response, apparent nutrient digestibility.

The layers fed with zero probiotic (Treatment 1) value in total protein, Globulin G/L compared to those on treatment $\mathrm{T}_{2}, \mathrm{~T}_{3}$, and $\mathrm{T}_{4}$ diet. However Albumin, total protein, globulin $\mathrm{G} / \mathrm{L}$ did not differ significantly. Also Urea $(\mathrm{Mmol} / \mathrm{L})$, Creatinine $(\mathrm{Mmol} / \mathrm{L})$, ALT $(\mathrm{U} / \mathrm{L})$ ASL $(\mathrm{U} / \mathrm{L})$ and total cholesterol showed no significant difference $(\mathrm{P}<0.05)$ and the value obtained. This finding is not in agreement with (Mansuls, 2010 and Kurtoghu, 2004) who observed disease in some serum especially cholesterol.

Albumin values recorded for all diets were not statistically significant $(\mathrm{P}<0.05)$ from each other, this is similar to the findings of Al-Saiady (2010) who reported that probiotics supplementation did not have any effect on Albumin and hematological parameters. Globulin values recorded for the diet were not statistically significant $(\mathrm{P}<0.05)$ from each other. Similarly Al-Saiady (2010) reported that probiotics supplementation did not have any effect on globulin and haematological parameters.

This is in agreement with result by Al-Saiady (2010) who reported that probiotic supplementation did not have any effect on globulin and haematological parameters. The mean values for urea were not significantly $(\mathrm{P}<0.05)$ different. Creatinine, ALT (U/L), AST (U/L) were also similar between treatments.

The result obtained showed that probiotic (4-Bac Extra) supplementation had no significant effect on any of the haematological traits measured $(\mathrm{P}<0.05)$. This is similar to reports of Chen et al. (2005) that haematology and serum chemistry parameters, $\mathrm{RBC}, \mathrm{WBC}$ and lymphocyte were not affected by the dietary treatments $(\mathrm{P}>0.05)$. According to La Ragione et al., 2001, Dimcho et al. (2005) and Knowles et al. (2000) the addition of probiotic did not affect RBC, WBC, haemoglobin and platelet, total protein and total cholesterol concentrations significantly.

\section{CONCLUSION}

The results obtained from the experiment conforms to the suggestion by some authors that some effects of 4-bac Extra probiotics are only slight. However, because of the abuse of antibiotic, it has provided safe alternative and reduced spread of diseases. It suffice to state that there is a relationship between 4-bac Extra supplementation levels and nutrients digestibility, biochemical, and hematological characteristics as the $15 \%$ inclusion level of 4Bac-Extra level in this trial had positive effect on digestibility of nutrients by the layers. The use of 4-bac Extra probiotics at all levels in diets of layers had higher economic advantage compared with the control. Therefore, 
Effects of 4BAC-Extra Probiotic Supplementation Levels on Nutrient Digestibility and Blood Parameters of Sasso Laying Hens

the use of probiotics at $10 \%$ inclusion rate is recommended to enhance the health status of birds against infection, diseases, preserve the birds and ensured stability on serum indices of the birds

\section{Acknowledgement}

The authors sincerely acknowledgement the support of African Chicken Genetic Gains Project for donating the experimental birds and the Department of Animal Science, Nasarwa State University Keffi

\section{REFERENCES}

1. A.O.A.C (2006). Association of Official Analytical Chemists. Official Methods of Analysis. $18^{\text {th }}$

2. Ahamefule, F.O., Obua, B.E., Ukweni, M.A., Oguike, M.A and Amaka, R.A. (2008). Haematological and biochemical profile of weaner rabbits fed raw or processed pigeon seed meal based diets. African J. Agric. Res., 3:315-319.

3. Ajagbonna, C.P., Onifade, K.I. and Suleiman, U. (1999). Haematological and biochemical changes in rats given extracts of Calotripics procera. Sokoto J. Vet. Sci., 1:36-42.

4. Al - Saiady, M. Y. (2010). Effect of probioticbacteria on immunoglobulin G concentrationand other blood components of newborn calves.Journal of Animal and VeterinaryAdvances 9(3):604 - 609.

5. Ari, M. M., Iji, P. A. and Bhuiyan, M. M. (2016) Promoting the proliferation of beneficial microbial populations in chickens World's Poultry Science Journal. 72:785-792 doi:10.1017/S0043933916000763.

6. Aro, S. O. and Akinmoegun, M. B. (2012). Haematology and red blood cell osmotic stability of pigs fed graded levels of fermented cassava peel based diets. Proc. 17th Annual Conf. of Anim. Sci. Assoc. of Nigeria (ASAN), 152-153.

7. Chen, Y. J., Son, K. S.,Min, B. J.,Cho,J. H., Kwon,O. S., andKim,I. H.,(2005). Effects of Dietary Probiotic on Growth Performance, Nutrients Digestibility, Blood Characteristics and Faecal Noxious Gas Content in Growing Pigs.Asian-Aust. Journal ofAnimal Science Vol 18, No. 10: 1464 - 1468.

8. Corcoran, B.M., Stanton, C., Fitzgerald, G.F. and Ross, R.P. (2005). Survival of probiotic lactobacilli in acidic environments is enhanced in the presence of metabolizable sugars. Applied and Environmental Microbiology, 71 (6): 3060-3067.

9. Dierck (1989). Biotechnology aids to improve feed and feed digestion Enzymes and Afermentation. Arch Animal Nutrition. Berl. 1989;39:241-261 (pubmed): 1157-61

10. Dimcho D., Svetlana B., Tsvetomira S and Tatiana V. (2005). Effect Of Feeding Lactina Ducklings. Trakia Journal of Sciences, Vol. 3, No. 2, pp 22-28, 2005. http://www.uni-sz.bgedition (W. Horwitz Editor). Washington D.C.

11. Duncan, D. B. (1955). "Multiple range and multiple F tests". Biometrics. 11: 1-42.

12. Genedy Salwa, G. and Zeweil, H. S. (2003). Evaluation of using medicinal plants as feed additives in growing Japanese quail diets. The $68^{\text {th }}$ Scientific Conference of Polish Animal Production Society, 9-12 September, Krakov, Poland.

13. Ibrahim, K.A., Mahmoud-Faten, A. and Abd-Elhalim, H.S. (2005). Comparison of the efficacies of commercial probiotics on growth performance, carcass characteristics and some plasma constituents of broiler chicks. Suez Canal Veterinary Medicien Journal, 8: 1-18.

14. Jain, N. C. (1986). Schalms Veterinary Haematology . 4 th ed. Lea and Febiger, Philadelphia, U. S. A.

American Research Journal of Agriculture

Page 7 
Effects of 4BAC-Extra Probiotic Supplementation Levels on Nutrient Digestibility and Blood Parameters of Sasso Laying Hens

15. Jain, N. C. (2010). Growth and reproductive response of swine fed fermented cassava tuber wastes. Ph.D Thesis University of Ibadan, Nigeria, 1-176.

16. Knowles, T. G., J. E. Edwards, K. J. Bazeley, S. N. Brown, A. Butterworth and Warriss. P. D. Koeneet (2004). Immunodulation by probiotic lactobacilli in layer cited by 197.

17. Kurtoglu, V., Kurtoglu, F., Seker, E., Coskun, B. and Balevi, T. (2004). Effect of probiotic supplementation on laying hen diets on yield performance and serum and egg yolk cholesterol. Food Additives and Contaminants, 21(9): 817-823.

18. La Ragione, R. M., Casula, G. Cutting, S. M. and Woodward, M. J. (2001). Bacillus subtilis spores competitively exclude Escherichia coli078:K80 in poultry. Vet. Microbiol. 79:133 - 142.

19. Mansuls, N.H. (2010). Effect of Probiotic Bacteria Utilization on Serum Cholesterol and Triglycrides Contents and Performance of Broiler Chickens. Global Veterinaria, 5(3): 184-186.

20. Mountzouris, K., Tsitrsikos, P., Palamidi, I., Arvaniti, A., Mohnl, M., Schatzmayr, G. and Fegeros, K. (2010). Effects of probiotic inclusion levels in broiler nutrition on growth performance, nutrient digestibility, plasma immunoglobulins, and cecal microflora composition. Poultry Science,89(1): 58-67.

21. Nawaz, H., Abbas, I., Mubarak, A. (2016). Effect of probiotics on growth performance, nutrient digestibility and carcass characteristics in broilers. Journal of Animal and Plant Sciences 26 (3): 599-604.

22. O'Sullivan, M.G., Thornton, G., O'Sullivan, G.C. and Collins, J.K. (1992) Probiotic bacteria: myth or reality. Trends Food Sci Technol3, 309-314.

23. Pauzenga, U. (1985). Feeding Parent Stock. Zootech. International. pp. 22-25.

24. Uko, O.J., Afaja, A.M. and Tanko, H.B. (2000). Weight gain, haematology and blood chemistry of rabbits fed cereal offals. Sokoto J. Vet. Sci., 2:18-26.

25. Zhang, X.,Tsuruta, S.,Andonov, S., Lourenco, D.A.L., Sapp, R.L.,Wang, C. andMisztal, I. (2015). Relationships among mortality, performance, and disorder traits in broiler chickens: a genetic and genomic approach. Poultry Science, 97 (5): 1511-1518.

Citation: Haruna, H. S., Ari, M.M., Adua, M.M., Yakubu, A. "Effects of 4BAC-Extra Probiotic Supplementation Levels on Nutrient Digestibility and Blood Parameters of Sasso Laying Hens". American Research Journal of Agriculture, vol 5, no. 1, 2019, pp. 1-8.

Copyright (c) 2019 Haruna, H. S., Ari, M.M., Adua, M.M., Yakubu, A. This is an open access article distributed under the Creative Commons Attribution License, which permits unrestricted use, distribution, and reproduction in any medium, provided the original work is properly cited. 